IRA-International Journal of Management \& Social Sciences

ISSN 2455-2267; Vol.07, Issue 01 (2017)

Pg. no. 65-72

Institute of Research Advances

https://research-advances.org/index.php/RAJMSS

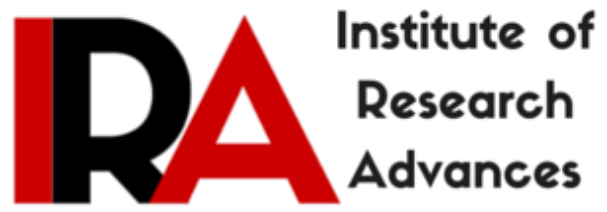

\title{
GST \& Evolution of Tax System in India
}

Jasmine V.M

Asst.Professor, St.Joseph's College (Autonomous) Devagiri, Kozhikode, India.

Type of Review: Peer Reviewed.

DOI: http://dx.doi.org/10.21013/jmss.v7.n1.p8

\section{How to cite this paper:}

V.M., Jasmine. (2017). GST \& Evolution of Tax System in India. IRA-International Journal of Management \& Social Sciences (ISSN 2455-2267), 7(1), 65-72.

doi:http://dx.doi.org/10.21013/jmss.v7.n1.p8

(C) Institute of Research Advances

\section{(cc) EY-No}

This work is licensed under a Creative Commons Attribution-Non Commercial 4.0 International License subject to proper citation to the publication source of the work.

Disclaimer: The scholarly papers as reviewed and published by the Institute of Research Advances (IRA) are the views and opinions of their respective authors and are not the views or opinions of the IRA. The IRA disclaims of any harm or loss caused due to the published content to any party. 


\begin{abstract}
Goods and Service Tax (GST) is a new tax-reform that India going to experience from July $1^{\text {st }}$ 2017. GST is a comprehensive tax collection system which will subsume many direct as well as indirect taxes. Currently we have Value Added Tax system for collecting indirect tax by the states. It has been introduced as indirect value added tax into Indian Taxation system from 01st April 2005. Approximately 193 countries in the world employed VAT. In order to give uniformity in tax collection and to avoid cascading effect of tax GST has been studied and going implement throughout the country. In this context this paper is an attempt to understand historical development, structure of Indian Taxation system, working, features, Impacts of GST in a simple manner.This paper concludes with some suggestions which will be helpful for smooth implementation of GST.
\end{abstract}

Key words: GST, VAT, GSTN, IGST, SGST

\title{
INTRODUCTION
}

Great financial restructuring is going on in India as part of its ambition to become a leading global economy. Government has taken various steps during the last few years for ease of doing business. Policies like liberalization, promotion of FDI, demonetization, digitalization of economy etc should be viewed in this context. One of the biggest and important developments is related with the structural reformation of Indian tax system. Post liberalization of Indian economy, many felt taxation was one of the key area were reforms are urgently required. As tax is the major source of income for any government, attempt for reformation may be viewed by other stake holders very seriously and doubts may be aroused due to fear of loss of revenue. Taxation is an enforced contribution imposed by the government for goods and services. Constitution has given powers to the union government, state governments and local bodies to collect tax. Article 265 of the Constitution states that "No tax shall be levied or collected except by the authority of law." Another criterion for collecting tax is that, law should be passed either by parliament or by state legislative. Article 246 of Indian constitution gives legislative powers including taxation between state legislature and parliament of India through its schedule-VI. India is going to experience major change in the system of tax collection after implementing GST (Goods and service tax), the newly proposed taxation combines most of the existing central and state taxes. It is a comprehensive indirect tax on manufacture, sale and consumption of goods and service throughout India. In this context this paper is an attempt to understand the expected developments happened in relation with GST.

\section{STATEMENT OF THE PROBLEM}

Current financial year, 2016-17, India may exercise some reforms in taxation. Goods and Service Tax is an attempt to bring uniformity in collection of tax . This system will avoid many short comings of present system of tax. At the same time it raises challenges towards state revenue and related aspects. This paper studies the historical development of Indian tax system, development of GST and its features. Thus it is an attempt to get basic knowledge about structure and reforms of Indian Taxation. It examines the working of GST, impacts and Challenges related with GST implementation. The paper has been concluded with some suggestion for smooth implementation of GST in India

\section{OBJECTIVES}

1. To understand the historical development of tax system in India.

2. To gain insight on the present status of GST bill In India

3. To understand GST and its features.

\section{SOURCES OF DATA}


The study has been conducted mainly on the basis of secondary data, literature review and personal interviews with experts, Journals, research papers, web resources and newspaper articles were used for gathering relevant data.

\section{LITERATURE REVIEW}

Many studies have been conducted on GST. Some of the relevant studies in this context are summarized below to gain a theoretical perspective on GST implementation.

- Nishita Gupta studied the relevance of implementing GST in India through her paper "Goods And Service Tax: It's Impact On Indian Economy". She tried to list out the shortcomings of present taxation system.

- In another study, Anshu Jain examined the possible impacts, implications and policies of introduction of GST in India .It also explain the development of Tax system in the world.

- Mohd Azham Khan tried to explain the significance of GST in India and its prospects to generate income for the states. This paper also made an attempt to understand how far GST is transparent compared to other taxation system.

- Keshap PK in his paper discusses the stages of development of GST in India. It also list out the various taxes which are included and excluded in GST.

\section{HISTORY OF INDIAN TAX SYSTEM}

If we analyse history of tax system, the first known system of taxation was in ancient Egypt around 3000BC- $2000 \mathrm{BC}$. Pharoah of that time collected revenue from the people. Bible also mentioned about allocation of crops towards usage and for giving tax. "Manusmruthy" and "Arthashastra" of India also gives indication about tax payment. Traders and Artisans were supposed to give $1 / 5$ of their profits in silver or gold while agriculturists were to pay $1 / 6$ or $1 / 8$ th or $1 / 10$ th of their production. Arthsastra have mentioned about schedule, time, manner and quantity of payments like land revenue was fixed at 1/6th of the production. During the period of Aurangaseeb, he charged tax on his Hindu subjects by the name "Jizya". Koutilya also described in great detail the system of tax administration. In British India Tax system was first introduced in the year 1860 by Sir. James Wilson, first Finance Minister of British India in order to cover the loss sustained by the government on account of the Military Mutiny -1857. In 1918 a new income tax has implemented and was replaced by another act in 1922. Under British rule, they set up administrative and taxation systems. There were two taxes namely direct tax and indirect tax. This was remained in force up to the assessment year 1961-62 with a number of amendments from time to time. Later Finance Ministry has introduced income tax Act 1961 which was approved by the Parliament .This came in to force on 1st April 1962. This applies to whole India and Sikkim including Jammu and Kashmir.

\section{THE TAX SYSTEM AND STRUCTURE IN INDIA}

The central board of revenue or department of revenue under Ministry of Finance, Government of India is the apex body charged with the administration of taxes. It came in to existence as a result of Central Board of Revenue Act 1924.Due to the difficulty in administration of both direct and Indirect tax, it has been split in to CBDT (Central Board of Direct Taxes) and CBEC (Central Board of Excise and Customs) in the year 1964 by Section 3 of Central Board of Revenue Act 1963. 


\section{CENTRAL BOARD OF DIRECT TAXES}

CBDT provides inputs for policy and planning of direct taxes in India. It is also responsible for administration of the direct tax laws through Income Tax Department. CBDT, a statutory authority functioning under Central Board of Revenue, is headed by Chairman and have 6 members from IRS.

\section{INCOME TAX DEPARTMENT}

It acts under revenue department under ministry of finance. Income tax department is responsible for administering direct taxation acts passed by parliament.

\section{CENTRAL BOARD OF EXCISE AND CUSTOMS (CBEC)}

CBEC deals with the task of formulation of Policy relating to levy and collection of Customs and central excise duties and service tax. Prevention of smuggling and administration of matters relating to customs, central excise, service tax and narcotics etc. comes under the purview of CBEC. CBEC is headed by chairman and five members.

\section{TAX REFORMS}

\section{VALUE ADDED TAX AND GOOD AND SERVICE TAX}

VAT is type of consumption tax that is collected incrementally based on value added at each stage of production. VAT is major source of revenue for Indian states. . VAT has been introduced as indirect value added tax into Indian Taxation system from 01st April 2005. Starting with Haryana, VAT has been implemented in all the states and union territories of India by 02nd June2004 except Andaman \& Nicobar Islands and Lakshwadeep. Approximately 193 countries in the world employed VAT including all OECD members except US. VAT is known as GST in some countries. Amendment no. 122 in constitution was introduced in parliament in the year 2014 which proposes a National VAT (GST) to be implemented in India. A 21 member committee was formed look in to the proposed law.

\section{GOODS AND SERVICE TAX}

According to article 366 of 122nd constitutional amendment bill "goods and service tax means any tax on supply on goods or service or both except taxes on the supply on alcoholic liquor for human consumption".

\section{JOURNEY OF GST IN INDIA}

$>$ Union Govt. appointed an empowered committee headed by Sh. Asim Das Gupta (finance minister of West Bengal)to design GST model for the nation.

$>$ In the budget in 2006 Union Government has announced in GST would be introduced from April 2010.

Empowered committee released first discussion paper on GST in November 2009.

$>$ In December 2009, 13th Finance commission released its report on GST .

$>$ In 2011 the constitution bill was introduced in parliament on GST.

$>$ In August 2013 standing committee on finance tabled its report on GST bill

$>$ Bill lapsed with Lok Sabha in December2014.

$>$ 122nd amendment bill has been again introduced in Lok Sabha in march 2015.

$>$ Rajya Sabh passed GST bill on 3rd August 2016.

$>$ Lok Sabha passed GST bill on 08th August 2016.

$>$ President approved GST Bill.

$>$ In March 2017union government agreed with the demand that GST rate must not be above $18 \%$. 
April2017 Parliament approved GST bill(compensation to states)

IMPORTANT DECISIONS OF EMPOWERED COMMITTEE ON GST

1. GST threshold was set at 10 lakh for northeast hill states and 20 lakhs for other states in the GST council meet. Centre and states agreed that up to 1.5 crore will be assessed by states and above that will be assessed by centre and state.

2. As per decision made by whole will of GST council on November 2016 tax rates would be at 04 slabs. i.e. $5 \%, 12 \%, 18 \%$ and $28 \%$. Luxury at $28 \%$ and daily needs will be taxed at $5 \%$.

3. In March 2017 GHST council approved two crucial legislations. State GST and Union Territory GST bill.

\section{WORKING OF GST}

Through a simple example it can be understood more clearly. Suppose a manufacturers buys raw materials for Rs 100/- which includes tax of Rs.10/-. When he manufacturers with this raw material, he adds some value to it for eg Rs.30/-. Then the total value become 130/-(10+90+30).Suppose tax is Rs. 105/- , then the tax on RS. 130/-n will be Rs. 13/-.But he has already paid tax while on his purchase of raw materials (Rs.10/-). Then the effective GST incidence on the manufacturer is only Rs. 3(13-10)

When it passes over to wholesaler he adds his margin for eg Rs. 20/-. The gross value will be Rs. 150 and tax on this amount will be Rs. 15/-. Under GST he can set off on his output against the tax on his purchased goods from manufacturer (Rs. 13/-). The effective GST will be only (15-13) i.e. Rs.2/-

When retailer buys from wholesaler, he adds his margin (Rs. 10/-) then it becomes 160/-Tax on this will be Rs. 16/-. After setting off this tax against tax he has paid on his purchase (Rs. 15/-), the effective GST incidence on himself to Rs $1 /$ - and the total tax paid becomes only $10+3+2+1=16$

\section{NON -GST REGIME}

There is cascading burden of tax on tax. In the above case manufacturer buys raw materials for Rs 100/-(10/- tax). He add value (30) then the total value of item become 130 and tax on it will be 13/-. Because of non availability of set off against the Rs.10/-, the goods are sold to wholesaler for Rs. 143/$(130+13)$. Same thing will happen in all stages. Thus under non GST regime a customer have to pay RS.208.23/- for the product which is available at Rs.166/- under GST.

\section{DRAW BACKS OF VAT}

1. We have VAT at Central and State Level. But the Central VAT or CENVAT mechanism extends tax set offs only against central excise duty and service paid up to the level of production.

2. Other limitation is that VAT system like CENVAT does not extend to value addition by the distributive trade below the stage of manufacturing. Even manufacturer cannot claim set offs against other central taxes, such as additional excise duty and surcharge.

3. State VAT covers only sales. Sellers can claim credit only against VAT paid on previous purchases

4. VAT also does not subsume a host other taxes imposed within the state such as Luxury and Entertainment tax, Octroi etc

\section{FEATURES}

In 1954 France adopted GST as its indirect taxation system and became the first country to adopt GST. This system ensures increased revenue through transparent and unbiased manner. Most of the countries adopt single unified GST. But Brazil \& Canada follows dual system of GST. India also indents to adopt this dual model. 
1. GST have two component-CGST and SGST.

2. In GST regime, pay first and get refund is preferred.

3. Section 7 and 4 of Model GST Act 2016 sets out that CGST/SGST and IGST shall be levied on all intra state and interstate supplies of goods and services respectively.

4. The two legs upon which the levy of GST stands are "time of supply" and "place of supply".

5. Time of supply determines the exact time at which the liability to pay the tax arises is provided in the GST and place of supply which determines whether CGST/ SGST that is applicable is traceable to the IGST Act. Section 5 and 6 of the IGST provides principles regarding this.

6. Sec7(2) of CGST /SGST provide for tax on reverse charge. Sec 4(3) of IGST provides for tax on importation services.

7. GST is applicable to all transactions of goods and services made for consideration except for exempted goods and services.

8. The Central GST and State GST are to be paid to the accounts of the Centre and State individually.

9. GST will reduce the prices of products

10. GSTN - GST Network is to be operated. It is a nonprofit organization, formed to create a platform for all the concerned parties like stakeholders, Government and tax payers to collaborate on a single portal.

11. The Centre will levy IGST on interstate supply of goods and services.

12. Import of goods will be subject to basic custom and IGST.

13. GST is defined as a tax on supply of goods and services other than alcohol for human consumption.

14. GST will subsume all central, state taxes.

15. Petroleum and petro products hall be subject to GST.

16. GST may be levied on the sale of news paper and advertisement, means substantial increment in revenue for the Govt.

17. The apex body of policy making for GST is GST Council. The members of GST council comprises of Central and the State Ministers in charge of the Finance Portfolio.

18. The power to laws in respect of supplies in course of interstate trade or commerce will be vested on the Union Govt.

19. The state will have the right to levy GST for internal state transactions including services.

20. Both CGST and SGAT would be levied on the basis of destination principle, means imports will be subject to GST, while exports would be zero rated. In the case of interstate transactions within India, state tax would apply in the state of destination as opposed to that of origin.

21. In addition to the IGST, in respect of supply of goods, an additional tax up to $1 \%$ has been proposed to be levied by the Centre. Revenue from this tax is to be assigned to origin state.

\section{IMPACTS OF GST}

1. Services are expected to be taxed with 3 slabs 5\%,12\% and $18 \%$ and GST council is yet to arrive at a final decision.

2. Oil Companies like ONGC are expected to face higher tax burden. Because when GST is implemented, due to clipping of existing tax breaks and higher tax rate, they have to suffer this heavy tax.

3. Five hydrocarbons are excluded from GST which will have an impact on the downstream industries and economy as a whole. Because these, hydrocarbons are critical components of various industries, it will lead to cost escalation economy.

4. In the context of goods purchased from one state and to be sold in another state, a $2 \%$ Central Sales Tax levied now, the proceeds will go to the state of origin. This will be replaced by much higher integrated GST and that will result additional stranding of tax. 
5. Operational cost of oil companies will be increased after GST. This will have a cascading effect across the supply chain.

6. There will be "compliance cost increment" ,means refineries using crude oil on which they pay excise duty VAT and Cesses, will have to keep separate books of accounts . Petrol, diesel and Jet fuel that will continue to attract these taxes while towards LPG, Kerosene and other Petrochemicals GST is applicable.

7. The offshore works contracts will come under GST. Service tax levied by the Centre, which currently (under VAT) covers only $40 \%$ of the value of such contract will be replaced by GST that will apply to its entire value.

8. Logistics are highly benefited .Studies estimates that the average logistics cost in India to be $13-14 \%$ of GDP.

9. Structural re-engineering of logistic net work will happen after GST.

10. Under current regime, business have the option to file manual Chelan, new law requires them to comply through online mode. Registered person is expected to report through GSTN-1,2 \&3 forms.

11. GST would open FDI.

12. GST council has approved 4 tier tax slab 5,12,18 and $28 \%$ within overall cap of $40 \%$, in addition cess will be levied on demerit goods like luxury, car, aerated drinks and tobacco products.

13. State income will come down for a time period and that will affect its growth rate. Now new bill to compensate states for implementation of GST has been accepted by the parliament.

\section{SUGGESION AND CONCLUSION}

Implementation of GST will generate various doubts and confusion among the people. To overcome this some suggestions were listed here:

1. Small retailers should get awareness classes regarding the benefits of GST.

2. They should be trained and helped to register in GSTN.

3. Educational institution should make arrangement to conduct classes in GST.

4. Tax collecting officers should be trained and tested to know whether they are capable handling new situations.

5. Government should arrange online/telephonic helpdesks or helping hands for rural area.

Goods and Service Tax is a new major change towards taxation system in India. After implementing GST prices of products will come down at the same time revenue from the tax will increase. But now also there are some confusion about some aspects of its decisions and success of implementation.

\section{REFERENCES}

1. NISHITA GUPTA, Goods And Service Tax: It's Impact On Indian Economy- CASIRJ Volume 5 Issue 3 [Year - 2014] ISSN 2319 - 9202 International Research Journal of Commerce Arts and Science http:www.casirj.com Page 126

2. Anshu Jain , An Empirical Analysis On Goods And Service Tax In India: Possible Impacts, Implications And Policies- Volume 2 Issue 1 January 2013 International Manuscript ID : ISSN23194618-V2I1M5-012013

3. Mohd Azham Khan 'Goods and Service Tax in India: Prospects for States'- Budgetary Research Review, www.budget.finate. ro

4. Keshap PK "Goods And Service Tax In India"- Journal of global Economics OTHER REFERNCES 
1. Goods and Service tax, Cover story from magazine named Contemporary issues and awareness October 2016.

2. Goods and Service Tax, from Magazine named Chartered Accountants.

3. Amit Kumar Dubey and Pooja Shukla, Goods and Service in India: Creating Single Market by Single Indirect Tax, Imperial Journal of Interdisciplinary Research (2016)

Webiliography:

www.financialexpress.com

www.gstindia.com

www.gstindiaonline.com 